\title{
Article \\ The Role of Ambivalent Sexism, Punitiveness, and Ability to Recognize Violence in the Perception of Sex Offenders: A Gender-Perspective Analysis
}

\author{
Carmen M. Leon ${ }^{1}\left(\mathbb{D}\right.$ and Chiara Rollero ${ }^{2, *}$ (D) \\ 1 School of Law, University of Castilla-La Mancha, 02071 Albacete, Spain; carmen.leon@uclm.es \\ 2 Department of Psychology, University of Turin, 10124 Turin, Italy \\ * Correspondence: chiara.rollero@unito.it
}

Citation: Leon, C.M.; Rollero, C. The Role of Ambivalent Sexism, Punitiveness, and Ability to Recognize Violence in the Perception of Sex Offenders: A Gender-Perspective Analysis. Sexes 2021, 2, 495-508. https://doi.org/10.3390/ sexes2040039

Academic Editor: Joana Carvalho

Received: 8 November 2021

Accepted: 3 December 2021

Published: 8 December 2021

Publisher's Note: MDPI stays neutral with regard to jurisdictional claims in published maps and institutional affiliations.

Copyright: (C) 2021 by the authors. Licensee MDPI, Basel, Switzerland. This article is an open access article distributed under the terms and conditions of the Creative Commons Attribution (CC BY) license (https:// creativecommons.org/licenses/by/ $4.0 /)$.

\begin{abstract}
Sexual violence is a public health problem that affects not just the victim, but the offender and the surrounding communities. Research shows that public perceptions regarding the perpetrators of such offenses are of critical importance since citizens' insights are a major force in the creation and implementation of sex offender policies. This study aimed to analyze, from a gender perspective, public perceptions about sex offenders in an Italian population sample $(N=768 ; 62.0 \%$ women, $M=32.8$ years old). To do so, the Perceptions of Sex Offenders Scale (PSO) $(\alpha=0.82)$ was used. The explanatory variables included in the study were the General Punitiveness Scale (GPS), the short versions of the Ambivalent Sexism Inventory (ASI), and the Ambivalence toward Men Inventory (AMI), as well as awareness about subtle forms of violence. Results showed that women reported higher levels of sex offenders' risk perception. At the same time, it was found that men outscored women on the endorsement of stereotypes toward such perpetrators. Finally, findings revealed similarities and differences between women and men regarding correlates of perceptions about sex offenders. Implications for research and public policy in this area are discussed.
\end{abstract}

Keywords: sex offenders; public perception; gender perspective; ambivalent sexism; punitivism; ability to recognize violence

\section{Introduction}

Sexual violence is a worldwide public health problem that has a profound impact on the physical, emotional, mental, and social well-being of victims [1]. Global estimates indicate this form of violence affects women disproportionately; for this reason, the Istanbul Convention recognizes sexual violence as a form of gender-based violence against women [2]. For instance, estimations indicate that $43.6 \%$ of women in the United States (U.S.) have experienced some form of contact sexual violence in their lifetime, and approximately one in five women $(21.3 \%)$ reported completed or attempted rape at some point in their lifetime. In the case of men, nearly a quarter of them in the U.S. $(24.8 \%)$ have experienced some form of contact sexual violence in their lifetime [3]. Similar estimations are found at the European level, where the study conducted by the European Union Agency for Fundamental Rights (FRA) revealed that one in ten women (11\%) indicated having experienced some form of sexual violence since the age of 15 [4].

As mentioned, the consequences of sexual violence affect both physical (e.g., bruising and genital injuries) and psychological (i.e., depression, anxiety, and suicidal thoughts) dimensions. Moreover, victims may suffer from post-traumatic stress disorder and experience reoccurring reproductive issues. Sexual violence is also linked to negative health behaviors (e.g., smoking, alcohol abuse, and drug use) and is connected to other forms of violence, such as being a victim of intimate partner violence in adulthood [3].

Due to the irrefutable harm to the victims, as well as the impact on loved ones and communities, sexual violence creates a climate of violence and fear [5]. As they try to make 
sense of what happened, loved ones (e.g., parents, friends, partners of the survivor) may experience similar reactions and feelings to those of the survivors. Schools, workplaces, neighborhoods, campuses, and cultural or religious communities may also feel fear, anger, or disbelief if a sexual assault happened in their community [5]. As a clear sign of how sexual violence could contribute to creating a climate of fear in society, research shows that women's higher fear of crime compared with men can largely be explained by fear of rape [6]. Research shows that women express greater overall levels of fear of crime and even higher levels of fear of sexual crimes in comparison with men [7]. These results are consistent across countries and populations (college students, general population) [8] and can be explained, partly, because of the shadow of sexual assault [9]. This hypothesis posits that women are more fearful of crime than men because many offenses have the potential to escalate into rape. Such is the case that the studies conducted in this field of research have found that the effect of gender on fear of nonsexual crimes becomes insignificant or even reverses when fear of rape is controlled for $[10,11]$.

Media reports also have an important role and contribute to endorsing a series of misperceptions and inaccurate information about sexual violence and its perpetrators that promote that "sex offenders tend to be a particularly reviled group of individuals in the public eye, frequently inspiring extreme negative emotional reactions, such as disgust, fear, and moral outrage" [12] (p. 832). Research on attitudes toward sex offenders suggests that public perception seems to be partly aligned with media portrayals, that is, negative emotions such as anger and fear, and that such reactions tend to be particularly strong regarding reoffending offenders and sexual offenses against children $[13,14]$. This highlights the need to further explore public perceptions about sex offenders, especially because public concerns and the anxiety associated with sex offenders both promote the increase of punitive and restrictive legislation, thus obstructing the sexual offenders' entrance back into the community [15].

\subsection{Public Attitudes and Perceptions about Sex Offenders}

Several studies have examined public attitudes and community perceptions regarding sex offenders and sex offender policies (among others, [16-18]). However, research in this field is still limited and mainly covers the Anglo-Saxon countries [19]. Consequently, comparable information about European countries is scarce.

Before concentrating on the relevance of studying public beliefs about sex offenders, the distinction between attitudes and perceptions should be addressed. According to Ref. [20], an attitude is defined as a "psychological tendency that is expressed by evaluating a particularly entity with some degree of favour or unfavour" (p. 1). Attitudes are composed of three components: cognition, affect, and behavior (for further information see [21]), and it is necessary that all of them are considered when studying attitudes toward sex offenders [22]. Perceptions, however, are more akin to stereotypical views and, thus, are primarily composed of knowledge-based attributions about a topic or entity $[23,24]$. The present study is focused on the examination of public perceptions about sex offenders since this constitutes a much narrower approach than examining attitudes [25], although most times both terms are used interchangeably.

\subsubsection{The Relevance of Studying Public Attitudes and Perceptions about Sex Offenders}

It is well established that the public's perception plays a powerful role in leading, informing, and influencing legislators in the creation of policies and laws [26]. Criminal justice policy does not only respond to the evolution of crime and the recommendations of experts, but it also meets public demands $[27,28]$. The sentencing and management of sex offenders is an example of a criminal justice issue where legislators have noticed the public's concern. As a result, legislative initiatives have sought to accommodate the public demands for more severe sanctions, longer prison sentencing, intensive monitoring when releasing offenders, and many other protective measures intended to protect the community [29]. However, since offender-specific laws have sometimes been made contrary to the existing 
empirical research, they have a great number of negative implications. For example, their inflexible and harsh nature hinders the efforts of offenders' reintegration and, in some instances, increases recidivism $[15,30]$. Offenders subjected to these policies also report negative personal effects, including loss of a job and relationships, being the target of harassment and threats, stress, shame, isolation, and embarrassment [31,32]. Consequently, these policies might hinder the main purposes of reducing recidivism and promoting public safety. For this reason, there is a need for further understanding why harsher sex offenders laws are supported despite being ineffective [29].

\subsubsection{Existing Research on Public Attitudes and Perceptions about Sex Offenders}

Evidence shows that public attitudes and perceptions about sex offenders are generally adverse $[16,33]$. Most studies show that community members endorse negative stereotypes about sex offenders, considering them dangerous and unpredictable [25,34]. It has also been found that sexual offenders are perceived as being unamenable to treatment and as having high rates of criminal recidivism $[35,36]$. In this regard, although evidence shows that sex offender recidivism rates are much lower than those of general offenders (less than $14 \%$ over a span of 5 years) [37], research reveals that community members' estimates of recidivism among sex offenders range from $59 \%$ to $74 \%[12,38]$.

In addition to stereotype endorsement and risk perception, studies analyzing public beliefs about sex offenders have focused on sentencing and management. Existing literature shows that many community members call for increased prison sentences or for offenders to spend longer periods of time on sex offender registries $[35,36,39]$. This phenomenon is known as punitiveness and has been defined as a general tendency to support harsher criminal justice policies, such as the offenders' increased subjection to long custodial sentences and the curtailment of basic human rights [40]. These public demands are especially common in the field of sex offenders. For instance, Ref. [41] surveyed undergraduate students and found that participants were less likely to endorse rehabilitation for sex offenders than nonsexual offenders and, alternatively, were more likely to endorse punitive responses toward sex offenders. Along similar lines, Ref. [13] found that people were pessimistic about sex offender rehabilitation and were skeptical about the effectiveness of criminal justice interventions. These attitudes persist in spite of research having demonstrating that the length of time offenders serve in prison does not significantly impact sexual recidivism [39,42].

Altogether, existing research demonstrates that misperceptions regarding sex offenders are common, which can feed the formation of negative attitudes [43-45], increase support for the introduction of harsher sex offender policies, and reduce support for sex offender treatment [46]. For all these reasons, the identification of the factors that influence community beliefs about sex offenders is the first step in the introduction of more effective policies in this field.

\subsection{Factors Influencing Public Attitudes and Perceptions about Sex Offenders}

Existing literature reveals that some factors can potentially influence attitudes and perceptions about sex offenders, such as educational level, gender, and age. However, findings regarding sociodemographic variables are inconclusive and little to no research has examined the relationship among other attitudinal and personal factors (e.g., ambivalent sexism and ability to recognize violence) and perception of sex offenders.

1.2.1. Sociodemographic Variables Influencing Public Attitudes and Perceptions about Sex Offenders

The most solid sociodemographic factor that has been found to be associated with attitudes and perceptions about sex offenders is the educational level, with more educated people expressing more positive attitudes (or, conversely, less negative attitudes) than those with lower qualifications [38,47]. Mixed results, however, have been found regarding gender and age. Although most studies have found that these variables are significant 
when predicting perceptions of sex offenders, the direction of the differences is inconsistent between studies (for more information, see [48-50]).

1.2.2. Other Attitudinal and Personal Factors Influencing Public Attitudes and Perceptions about Sex Offenders

Some studies have examined the role of indirect victimization (i.e., knowing a victim) on attitudes toward sex offenders. The majority of them have found no attitudinal differences between people who did or did not know a victim of a sexual offense [38,51,52]. However, Ref. [52] reported that participants who did know a sex offender expressed more positive attitudes toward them than those who did not know an offender. Nevertheless, findings show mixed results and Ref. [38] found no significant attitudinal differences between these two groups.

Another variable associated with perceptions toward sex offenders is punitivism. It seems reasonable that individual levels of punitiveness are related to attitudes toward sentencing and managing sex offenders since they are said to be a key driver of the political discourse around crime and punishment [53,54]. For example, Ref. [23], in the study where they proposed the creation and validation of the Perception of Sexual Offenders Scale (PSO), found a strong correlation between the Perceptions of Sex Offenders Scale and the General Punitiveness Scale $(r=0.77)$.

Ambivalent sexism may also influence beliefs about sex offenders. The theory of ambivalent sexism [55] posits that sexist attitudes encompass ambivalence on the part of each sex toward the other. Since most of the victims of sexual violence are women and perpetrators are men, sexism may have an important role in explaining these beliefs. Previous research has shown that sexism influences attitudes toward rape, as well as perceptions about rapists and victims [56,57]. Specifically, Ref. [58] concluded that people who scored higher in benevolent sexism tended to excuse the rapist more often than those who scored lower in benevolent sexism. Along similar lines, since ambivalence toward men reinforces gender hierarchy by characterizing men as inherently powerful and aggressive while admiring their traditional roles [59], it is expected that these beliefs also influence perceptions about sex offenders. To our knowledge, no studies have examined the impact of ambivalent sexism as a moderator of the perceptions toward sex offenders. Therefore, due to the relevance that both constructs might have in this field of research, the present study investigates the moderating role of ambivalent sexism toward women and the ambivalence sexism toward men on the perceptions toward sex offenders.

Finally, since a recent study reveals that, in respect to women, men have a greater tendency to accept beliefs that justify the use of violence against women, perceive a narrower range of behaviors as violent, and see violent behaviors against women as less serious, damaging, or inappropriate [59], in the present study we have included two dimensions of the list of behaviors harming women [60] (limitation of freedom and emotional abuse) with the aim to examine the impact of the awareness about subtle forms of violence on the public perceptions about sex offenders.

\section{Present Study}

Public perception of sex offenders is of great relevance for clinical, social, and political decision-making $[38,61]$. Although several studies have examined public attitudes and community perceptions toward sex offenders and sex offender policies, research is still limited, especially outside of the Anglo-Saxon context [19]. With the purpose of contributing to this field of research, the main objective of this study is to examine, from a gender perspective, the public perception of sex offenders in an Italian population sample. To do so, the Perceptions of Sex Offenders Scale (PSO) [23] is used as the outcome variable. Three factors that represent distinct aspects of the wider societal discourse about sex offenders and their management are underlined in this scale: (1) stereotype endorsement; (2) perceptions about the risks posed by sex offenders; and (3) public thinking about the best ways to sentence and manage such offenders. Analyses are executed from a gender perspective (i.e., disaggregating the results by sex) since women are disproportionately represented among 
sexual violence figures when compared to men. Based on Shaver's defensive attribution hypothesis [62], which claims that, since (sexual) offenders are predominantly male, men are more likely to identify with and less likely to blame offenders for their criminal activity than women are, therefore it is postulated that differences between women and men regarding public perceptions of sex offenders will emerge. Moreover, this study aims to analyze the relevance of a series of novelty variables (i.e., Ambivalent Sexism, Punitiveness, and Ability to Recognize Violence) on these perceptions. It is expected that findings contribute to the existing compared literature and allow obtaining a better understanding of how perceptions about sex offenders are formed.

Based on some theoretical postulates (i.e., the defensive attribution hypothesis and the shadow of sexual assault), it is expected that women, compared to men, will score higher in the "Sentencing and Management" and "Risk Perception" dimensions. However, it is expected that men, compared to women, will score higher in the "Stereotype Endorsement" dimension since some of the stereotypes regarding sex offenders are listed as rape myths. In this regard, it is well established that men endorse more myths about rape than women ([63] for a revision). Finally, it is anticipated that differences between women and men will emerge regarding the correlates of each of the three dimensions that comprise the PSO.

\section{Materials and Methods}

\subsection{Participants}

The study enrolled 768 Italian adults (62.0\% women). Their mean age was 32.76 years old (age range $=18-66, S D=13.18$ ). Among them, $63.9 \%$ were workers, $29.1 \%$ were students, and $7.0 \%$ were unemployed. Most of them (56.5\%) were single, $37.3 \%$ had a partner, and $6.3 \%$ were divorced or widowed. Finally, $31.0 \%$ of the participants reported having met a victim of a sex offense, whereas $14.9 \%$ stated that they had met a sex offender.

\subsection{Procedure and Measures}

The study protocol was approved by the Ethics Committee of the University of Turin, Italy (CERP 196412-23 March 2021). Participants were recruited using snowball sampling begun with postings by the researchers and their students. The link from the posting took subjects to a secure, anonymous online questionnaire where they read an informed consent form before beginning the study. Participants were also informed that their participation was voluntary, and they could discontinue the study at any time. No compensation was given for their enrollment.

The self-report questionnaire took approximately $20 \mathrm{~min}$ to complete, and it included the following measures:

1. The Ambivalent Sexism Inventory-short version $[55,64]$ including 12 items measuring Hostile Sexism toward women, HS (6 items, e.g., "Once a woman gets a man to commit to her, she usually tries to put him on a tight leash", Cronbach's $\alpha=0.85)$ and Benevolent Sexism toward women, BS (6 items, e.g., "Women should be cherished and protected by men", Cronbach's $\alpha=0.82$ ). The items were rated on a 6-point Likert-type scale ranging from "strongly disagree" (0) to "strongly agree" (5).

2. The Ambivalence Toward Men Inventory—short version $[64,65]$ measuring Hostile Sexism toward men, HM (6 items, e.g., "Men will always fight to have greater control in society than women", Cronbach's $\alpha=0.79$ ) and Benevolent Sexism toward men, BM (6 items, e.g., "Men are more willing to put themselves in danger to protect others", Cronbach's $\alpha=0.83$ ). The items were rated on a 6-point Likert-type scale ranging from "strongly disagree" (0) to "strongly agree" (5).

3. The General Punitiveness Scale [40] including 8 items assessing agreement with popular statements about crime and punishment (e.g., "My general view towards offenders is that they should be treated harshly", Cronbach's $\alpha=0.77)$. Items were rated on a 6-point scale ranging from "strongly disagree" (1) to "strongly agree" (6).

4. Two dimensions of the List of Behaviors Harming Women [59,60]: Limitation of Freedom and Emotional Abuse. Limitation of Freedom includes 6 items investigat- 
ing participants' ability to recognize specific behaviors as restrictions to women's independence and autonomy (e.g., "Divesting a woman of her own earned money", Cronbach's $\alpha=0.94)$. Emotional Abuse includes 6 items referred to verbally and emotionally aggressive behaviors aimed at humiliating women (e.g., "Yelling at a woman", Cronbach's $\alpha=0.84$ ). Participants were asked to evaluate if each specific behavior was a form of violence against women. The items were rated on a 5-point Likert-type scale ranging from "it is not at all violence" (0) to "it is certainly violence" (4).

5. The Perceptions of Sex Offenders Scale, PSO [23] measuring attitudes toward sex offenders. It consists of 20 items that are scored on a 7-point Likert-type scale ranging from "strongly disagree" (1) to "strongly agree" (7). It has three subscales: sentencing and management (e.g., "People who commit sex offences should lose their civil rightse.g., voting, privacy", Cronbach's $\alpha=0.87$ ), stereotype endorsement (e.g., "Most sex offenders do not have close friends", Cronbach's $\alpha=0.83$ ), and risk perception (e.g., "Only a few sex offenders are dangerous"-reverse scored, Cronbach's $\alpha=0.70$ ).

6. A list of sociodemographic items.

\subsection{Data Analyses}

$T$-tests were performed to test gender differences on the study variables. Then, correlations between measures used in the study were carried out. Finally, to test our hypotheses, we performed three multiple regression models (stepwise method) replicated on each of the three dimensions of PSO (i.e., sentencing and management, stereotypes endorsement, and risk perception). In each regression model, the dimension of PSO was regressed onto: age, have met a victim of a sex offense, have met a sex offender, HS, BS, HM, BM, General Punitiveness, ability to recognize Limitation of Freedom, and ability to recognize Emotional Abuse. The models were tested within the male and the female sample separately. All statistical analyses were carried out using IBM SPSS Statistics version 27.0 software (IBM, Armonk, New York, NY, USA).

\section{Results}

$T$-tests were performed to assess gender differences on the study variables. As shown in Table 1, men outscored women on HS, BS, BM, as well as on the endorsement of stereotypes toward sex offenders. In contrast, women reported higher levels of HM and risk perception, as well as a higher ability to recognize limitation of freedom and emotional abuse as forms of violence. No significant gender differences emerged in relation to punitiveness and sentencing of sex offenders.

Zero-order correlations between scales were also carried out. As shown in Table 2, all the dimensions of Ambivalent Sexism were positively correlated. General Punitiveness was positively related to the three dimensions of PSO. The capacity to recognize Limitation of Freedom was negatively linked to HS, BS, BM, and General Punitiveness, whereas the ability to recognize Emotional Abuse was positively associated with BS, HM, and Limitation of Freedom. Finally, Sentencing and Management and Stereotype Endorsement were positively correlated with Ambivalent Sexism and General Punitiveness, and negatively with Risk Perception. This last was also positively linked to General Punitiveness, but negatively to HS, BS, BM, and Emotional Abuse.

Finally, multiple regression analyses were performed on each dimension of PSO within the male and the female sample separately. Concerning Sentencing and Management, as reported in Table 3, the model was significant in both genders and explained a good proportion of the dependent variable. Specifically, General Punitiveness was the strongest predictor for both men and women. In the male population, HS and the ability to recognize Emotional Abuse were also positively associated with Sentencing. On the contrary, for women HS was negatively related to Sentencing, whereas age, BS, and HM increased punitiveness toward sex offenders. 
Table 1. Gender differences on the study variables: means, standard deviations, and $T$-Test scores.

\begin{tabular}{|c|c|c|c|c|}
\hline & & Mean & $S D$ & $T$ \\
\hline \multirow[t]{2}{*}{ HS } & Men & 2.01 & 1.08 & $-9.89 * *$ \\
\hline & Women & 1.30 & 1.05 & \\
\hline \multirow[t]{2}{*}{ BS } & Men & 2.25 & 1.15 & $-3.09 * *$ \\
\hline & Women & 1.97 & 1.22 & \\
\hline \multirow[t]{2}{*}{$\mathrm{HM}$} & Men & 2.09 & 1.05 & $4.17^{* *}$ \\
\hline & Women & 2.43 & 1.11 & \\
\hline \multirow[t]{2}{*}{$\mathrm{BM}$} & Men & 1.83 & 1.10 & $-8.64^{* *}$ \\
\hline & Women & 1.16 & 1.00 & \\
\hline \multirow[t]{2}{*}{ General Punitiveness } & Men & 3.62 & 0.94 & -1.84 \\
\hline & Women & 3.48 & 1.00 & \\
\hline \multirow[t]{2}{*}{ Limitation of Freedom } & Men & 3.34 & 1.79 & $2.61 *$ \\
\hline & Women & 3.50 & 0.83 & \\
\hline \multirow{2}{*}{ Emotional Abuse } & Men & 2.38 & 0.99 & $2.16^{*}$ \\
\hline & Women & 2.52 & 0.85 & \\
\hline \multirow[t]{2}{*}{ Sentencing and Man } & Men & 3.14 & 1.19 & -0.58 \\
\hline & Women & 3.09 & 1.09 & \\
\hline \multirow[t]{2}{*}{ Stereotype Endorsement } & Men & 2.78 & 0.98 & $-5.64^{* *}$ \\
\hline & Women & 2.36 & 0.98 & \\
\hline \multirow[t]{2}{*}{ Risk Perception } & Men & 4.74 & 0.95 & $7.97 * *$ \\
\hline & Women & 5.22 & 0.70 & \\
\hline
\end{tabular}

Table 2. Pearson's correlations between variables.

\begin{tabular}{|c|c|c|c|c|c|c|c|c|c|}
\hline & 2. & 3. & 4. & 5. & 6. & 7. & 8. & 9. & 10. \\
\hline $\begin{array}{l}\text { 1. HS } \\
\text { 2. BS } \\
\text { 3. HM } \\
\text { 4. BM } \\
\text { 5. Punitiveness } \\
\text { 6. Limitation of Freedom } \\
\text { 7. Emotional Abuse } \\
\text { 8. Sentencing and Management } \\
\text { 9. Stereotype Endorsement } \\
\text { 10. Risk Perception }\end{array}$ & $0.54 * *$ & $\begin{array}{l}0.41^{* *} \\
0.53^{* *}\end{array}$ & $\begin{array}{l}0.73^{* *} \\
0.67^{* *} \\
0.46^{* *}\end{array}$ & $\begin{array}{l}0.40^{* *} \\
0.40^{* *} \\
0.29 * * \\
0.37^{* *}\end{array}$ & $\begin{array}{l}-0.20^{\text {** }} \\
-0.13^{\text {** }} \\
-0.05 \\
-0.23^{\text {** }} \\
-0.22^{\text {** }}\end{array}$ & $\begin{array}{l}-0.09 \\
0.10^{*} \\
0.11^{*} \\
0.02 \\
-0.09 \\
0.46^{* *}\end{array}$ & $\begin{array}{l}0.39 \text { ** } \\
0.48^{\text {** }} \\
0.41^{\text {** }} \\
0.42^{\text {** }} \\
0.67^{\text {** }} \\
-0.13^{\text {** }} \\
0.05\end{array}$ & $\begin{array}{l}0.49^{* *} \\
0.40^{* *} \\
0.27^{* *} \\
0.48^{* *} \\
0.26^{* *} \\
-0.14^{* *} \\
0.08 \\
0.37^{* * *}\end{array}$ & $\begin{array}{l}-0.28^{\text {** }} \\
-0.12^{*} \\
-0.07 \\
-0.27^{* *} \\
0.16^{* *} \\
0.04 \\
-0.14^{* *} \\
0.14^{* *} \\
-0.33^{* *}\end{array}$ \\
\hline
\end{tabular}

Table 3. Regression analyses predicting Sentencing and Management.

\begin{tabular}{lllll}
\hline & \multicolumn{2}{c}{ Men } & \multicolumn{2}{c}{ Women } \\
\cline { 2 - 5 } & Beta (SE) & $T$ & Beta (SE) & $T$ \\
\hline Age & $0.08(0.00)$ & 1.84 & $0.12^{* *}(0.00)$ & 3.56 \\
Have met a victim & $0.00(0.13)$ & 0.03 & $-0.03(0.09)$ & -0.74 \\
Have met an offender & $0.03(0.16)$ & 0.58 & $-0.01(0.11)$ & -0.27 \\
HS & $0.21^{* *}(0.07)$ & 3.27 & $-0.14^{* *}(0.05)$ & -2.90 \\
BS & $0.07(0.06)$ & 1.25 & $0.18^{* *}(0.05)$ & 3.21 \\
HM & $0.01(0.06)$ & 0.21 & $0.16^{* *}(0.04)$ & 3.80 \\
BM & $0.04(0.08)$ & 0.59 & $0.09(0.06)$ & 1.72 \\
General Punitiveness & $0.52^{* *}(0.06)$ & 10.80 & $0.57^{* *}(0.04)$ & 15.58 \\
Limitation of Freedom & $-0.07(0.07)$ & -1.40 & $0.07(0.05)$ & 1.76 \\
Emotional Abuse & $0.19^{* *}(0.06)$ & 3.96 & $-0.03(0.05)$ & -0.70 \\
\hline & Adjusted $\mathrm{R}^{2}=0.55^{* *}$ & Adjusted $\mathrm{R}^{2}=0.55^{* *}$ \\
& $\mathrm{~F}(10,277)=34.38^{* *}$ & $\mathrm{~F}(10,444)=54.17^{* *}$ \\
\hline
\end{tabular}

$\overline{* *} p<0.01$.

As seen in Table 4, even the model about Stereotype Endorsement was significant. For both genders, HS and the capacity to recognize emotional violence increased the endorsement of a stereotypical view of sex offenders. Furthermore, Stereotype Endorsement was associated with having met an offender for men and with BM for women. 
Table 4. Regression analyses predicting Stereotype Endorsement.

\begin{tabular}{lllll}
\hline & \multicolumn{2}{c}{ Men } & \multicolumn{2}{c}{ Women } \\
\cline { 2 - 5 } & Beta (SE) & $T$ & Beta (SE) & $T$ \\
\hline Age & $-0.00(0.00)$ & -0.06 & $0.02(0.00)$ & 0.58 \\
Have met a victim & $-0.03(0.14)$ & -0.47 & $-0.01(0.10)$ & -0.18 \\
Have met an offender & $0.14^{*}(0.17)$ & 2.43 & $-0.04(0.13)$ & -0.83 \\
HS & $0.39^{* *}(0.07)$ & 4.74 & $0.22^{* *}(0.06)$ & 3.70 \\
BS & $0.08(0.06)$ & 1.21 & $0.08(0.06)$ & 1.18 \\
HM & $-0.02(0.06)$ & -0.33 & $0.02(0.05)$ & 0.42 \\
BM & $0.09(0.08)$ & 1.05 & $0.20 * *(0.07)$ & 2.87 \\
General Punitiveness & $-0.02(0.07)$ & -0.25 & $0.09(0.05)$ & 1.84 \\
Limitation of Freedom & $-0.07(0.07)$ & -1.24 & $-0.09(0.06)$ & -1.76 \\
Emotional Abuse & $0.17^{* *}(0.06)$ & 2.76 & $0.13^{* *}(0.06)$ & 2.63 \\
\hline & Adjusted $\mathrm{R}^{2}=0.27^{* *}$ & Adjusted $\mathrm{R}^{2}=0.27^{* *}$ \\
& $\mathrm{~F}(10,275)=11.14^{* *}$ & $\mathrm{~F}(10,443)=17.17^{* *}$ \\
\hline ** $p<0.01{ }^{*} p<0.05$. & \multicolumn{2}{c}{}
\end{tabular}

As shown in Table 5, the model about Risk Perception was significant but in women explained a relatively low proportion of the dependent variable. Subjects higher on General Punitiveness perceived sex offenders as more dangerous, whereas those lower on HS and more able to recognize emotional abuse showed lower risk perception. Furthermore, perceived risk was positively linked with BS in men, and negatively associated with BM in women.

Table 5. Regression analyses predicting Risk Perception.

\begin{tabular}{lllll}
\hline & \multicolumn{2}{c}{ Men } & \multicolumn{2}{c}{ Women } \\
\cline { 2 - 5 } & Beta (SE) & $T$ & \multicolumn{1}{c}{ Beta (SE) } & $T$ \\
\hline Age & $-0.02(0.00)$ & -0.28 & $-0.01(0.00)$ & -0.12 \\
Have met a victim & $-0.09(0.13)$ & -1.55 & $-0.04(0.07)$ & -0.67 \\
Have met an offender & $-0.11(0.16)$ & -1.87 & $0.00(0.09)$ & 0.05 \\
HS & $-0.020^{*}(0.07)$ & -2.43 & $-0.28^{* *}(0.04)$ & -4.36 \\
BS & $0.16^{*}(0.06)$ & 2.42 & $0.03(0.04)$ & 0.42 \\
HM & $-0.13(0.06)$ & -1.87 & $0.10(0.04)$ & 1.75 \\
BM & $-0.16(0.08)$ & -1.84 & $-0.18^{*}(0.05)$ & -2.39 \\
General Punitiveness & $0.43^{* *}(0.06)$ & 7.09 & $0.25^{* *}(0.03)$ & 4.82 \\
Limitation of Freedom & $0.10(0.07)$ & 1.67 & $0.04(0.04)$ & 0.81 \\
Emotional Abuse & $-0.28^{* *}(0.06)$ & -4.54 & $-0.12^{*}(0.04)$ & -2.30 \\
\hline & Adjusted $\mathrm{R}^{2}=0.27^{* *}$ & Adjusted $\mathrm{R}^{2}=0.13^{* *}$ \\
& $\mathrm{~F}(10,280)=11.33^{* *}$ & $\mathrm{~F}(10,447)=7.44^{* *}$ \\
\hline ** $p<0.01^{* *} p<0.05$ & \multicolumn{2}{c}{}
\end{tabular}

${ }^{* *} p<0.01 ;{ }^{*} p<0.05$

\section{Discussion}

The aim of this study was to examine, from a gender perspective, the public perception of sex offenders in an Italian population sample. Since a limited number of studies have analyzed these beliefs in European countries [19], this research contributes to the existing knowledge from a comparative perspective. Moreover, the present study sheds light on the factors that modulate community beliefs by analyzing a series of novelty variables (i.e., Ambivalent Sexism, Punitiveness, and Ability to Recognize Violence) in this field of research. Another aspect that makes this study original is that analyses were conducted from a gender perspective, disaggregating the results by sex. Because women are, by far, the most frequent victims of sexual violence, it was postulated that women could have different perceptions about sex offenders when compared to their male counterparts.

As seen from the results of descriptive statistics, men were more hostile and benevolent toward women, as well as more benevolent toward men when compared with women. 
These findings are consistent with previous research $[59,66,67]$ and suggest that the endorsement of sexist attitudes differs according to gender. As sexism relegates women to hierarchically lower positions than those of men, it seems reasonable than men are more prone to sexist attitudes toward women. Moreover, it is not surprising than men scored higher than women on Benevolent Sexism toward men, since individuals with higher levels of BM consider men to be superior because of their "essential" role [59]. Additionally, findings show that men scored higher than women on the Stereotypes' Endorsement toward sex offenders, which indicates that men have more stereotypical thoughts about these offenders, such as "most sex offenders do not have close friends" and "most sex offenders are unmarried men". Considering that some stereotypes about sex offenders are listed as rape myths, this finding is consistent with previous research that shows that men endorse more rape myths than women [63]. On the other hand, women reported higher levels of Hostile Sexism toward men and Risk Perception of sex offenders, as well as a higher ability to recognize the Limitation of Freedom and Emotional Abuse as forms of violence toward women when compared to men. The results regarding HM and the ability to recognize violence are consistent with a recent study conducted in Italy (see [59] for implications). Especially remarkable is the finding regarding the Risk Perception of sex offenders, since it might give support to the defensive attribution hypothesis [62]. In this regard, women may express a higher Risk Perception of sex offenders because they are the main victims of sexual violence. Moreover, this finding might be at least partially explained by the shadow of sexual assault, which postulates that women's higher fear of crime compared with men can largely be explained by women's fear of rape [6]. In terms of Sentencing and Management of sex offenders, no significant gender differences emerged, thus suggesting no differences among groups regarding punitive attitudes. This is consistent with findings in the field of research on punitivism [27].

Regarding the results that emerged from correlations, it was found that General Punitiveness was positively related to all three dimensions of PSO. As Ref. [23] previously indicated, this reflects the fact that generalized punitiveness is associated with the existing support for sex offenders to be treated harshly by the courts and upon their reentry into the community, which supports the hypothesis that the "Sentencing and Management" dimension is a factor equating to punitiveness. Moreover, it might be justifiably supposed that General Punitiveness would be associated with Stereotype Endorsement and Risk Perception of sex offenders, since it seems reasonable to think that if the community perceives sex offenders as the most dangerous and recidivist offenders, people will demand more severe sanctions, long prison sentencing, and intensive monitoring when releasing offenders in order to keep them away from the community [29].

Along similar lines, "Sentencing and Management" and "Stereotype Endorsement" were positively correlated with Ambivalent Sexism and negatively correlated with "Risk Perception". These findings indicate that more sexist individuals have more distorted ideas about sex offenders, and that they also advocate harsher punishment and security measures regarding sex offenders. This is consistent with previous research in the field of punitiveness, which shows that conservatism (in which sexism could be placed) is one of the main explanatory variables of punitive attitudes $[27,68]$. On the contrary, results showed that "Risk Perception" was negatively correlated with Ambivalent Sexism. This implies that the more sexist individuals also perceived less risk about sex offenders. This might be explained because hostile sexist individuals may feel more self-confident and thus less vulnerable. Since this is just a possible explanation, future research could delve into the existing relationship between Hostile Sexism and Risk Perception of sex offenders.

As far as regression models' results are concerned, findings show that the correlates of the three dimensions of PSO are not so divergent for women and men, which is contrary to our expectations. Regarding General Punitiveness, results show that this variable was the most important when predicting both Sentencing and Management of sex offenders and their Risk Perception; and this was true for both women and men. As previously mentioned, these findings are consistent with those by Ref. [23] and seem reasonable since 
they express that more punitive individuals support the idea that sex offenders must be more harshly punished. Additionally, it makes sense that the more the community perceives sex offenders as dangerous and risky, the more they will support the idea that offenders must be harshly punished (i.e., General Punitiveness). An additional important finding is the one that reflects the relevant role of sexism (which in this study is much more important than political orientation). Specifically, results show that Hostile Sexism increased punitiveness toward sex offenders in the case of men and decreased punitivism in the case of women. Moreover, HS was associated with a greater endorsement of sex offenders' stereotypes, and it was negatively associated with the Risk Perception of sex offenders. Regarding Benevolent Sexism, women who scored higher in this dimension also scored higher in the Sentencing and Management dimension. Besides, men who scored higher in BS also scored higher in Risk Perception of sex offenders. These findings could be explained because Benevolent Sexism emphasizes the weakness and the need for women to be protected by men [55]. In this regard, if women are viewed as deserving men's protection and provision, it seems reasonable that more benevolently sexist individuals would be positioned in favor of increasing punishment toward sex offenders and perceiving them as risk perpetrators. In other words, these individuals could be more concerned about the damages that women can suffer (such as sexual violence), thus considering the necessity of protecting women by asking for harsher punishments.

In terms of ambivalence toward men, HM was only significant in the case of women in the "Sentencing and Management" model. Specifically, results show that women who scored higher on HM also scored higher on the "Sentencing and Management" dimension. Added to that, results regarding BM show that women who scored higher in BM also endorsed more stereotypes about sex offenders, as well as a higher risk perception. These results are consistent with the postulates of heterosexual hostility, which, in the words of Ref. [65], may occur on the part of women toward men as a result of resentment of male sexual aggressiveness. The authors pointed out that the threat of sexual violence has been popularly characterized as a means by which men control women to maintain inequality, and women's awareness of this threat has been shown to have profound effects on their attitudes and behavior. Altogether, findings regarding sexist attitudes reveal the relevance of these constructs in the analysis of perceptions about sex offenders.

Considering specifically the influence of the awareness about subtle forms of violence on how sex offenders are perceived, it was found that individuals who identify Emotional Abuse as a form of violence against women showed higher Sentencing and Stereotype Endorsement of sex offenders, but lower Risk Perception. These results confirm the importance of the ability to recognize Emotional Abuse on the perceptions about sex offenders. Moreover, according to literature [69-71], this might reflect that the individuals who perceive a range of behaviors as violent also see violent behaviors against women as more serious, damaging, or inappropriate. This could help to explain that participants who identify Emotional Abuse as a form of violence against women showed higher Sentencing and Stereotype Endorsement toward sex offenders. On the contrary, it was found that the ability to recognize Emotional Violence was associated with lower Risk Perception of sex offenders. In this regard, it could be hypothesized that people who are capable of recognizing less drastic manifestations of violence have a better understanding about perpetrators and are less influenced by beliefs that negatively affect sex offenders' Risk Perception.

Finally, it is important to highlight the failure of the "contact hypothesis" [72], which suggests that interpersonal contact between groups can reduce prejudice, since the results show that those who indicated knowing a victim or an offender did not differentiate their perceptions about sex offenders from the others. The only difference was found when predicting the "Stereotype Endorsement" dimension since results showed that men who know an offender endorse more stereotypes about sex offenders. This result is to some extent unexpected because it might be thought that knowing a real sex offender could help to reduce, or even eliminate, the false beliefs that surround them (among others, "most sex offenders do not have close friends" and "most sex offenders are unmarried 
men"). Future studies could delve into this relationship by asking the respondents about the sociodemographic profile of the sex offender(s) that they know. Before concluding, it is also considered relevant to point out that the sociodemographic variables were not significant in the models (the only sociodemographic variable that was significant was women's age, and solely in the model predicting the Sentencing and Management of sex offenders). This finding shows the greater relevance of attitudinal and personal variables of the respondents, such as sexism and punitivism, when compared to sociodemographic variables, in the prediction of perceptions about sex offenders.

Although this study provides an important contribution to the existing literature, limitations should be noted. The first one refers to the narrow generalizability of the sample. Although it should be noted that this study used a general population sample, the data used were collected by using a non-probability sampling. A further limitation identified is that the PSO employs a very broad singular definition of "sex offender". Given the heterogeneity of sex offenders with respect to victim type (e.g., child vs. adult) and offense characteristics (e.g., contact vs. non-contact), it is possible that perceptions regarding sex offenders vary as a function of sex offender type. Specifically, attitudes toward child sexual offenders may be largely different from those toward women offenders, as sexual offending against children represents a unicum, characterized by emotions that are excluded in other forms of violence. Finally, future research should investigate the role of moral foundations and religiosity. Indeed, perceptions of sex offenders may be affected by moral judgments, as well as by attitudes toward sex and sexuality rooted in religious norms. In the present case, the Catholic tradition of Italian society may have played a role in shaping a similar perception of offenders between men and women. Cross-cultural research may be helpful in addressing these questions, comparing societies with different moral and religious traditions.

\section{Conclusions}

Distorted perceptions of sex offenders and skepticism about the possibility of rehabilitating them create an atmosphere in which legislators feel compelled to enact tougher sentencing laws [73]. Additionally, evidence shows that negative perceptions about sex offenders hinder their reintegration [23]. Altogether, this emphasizes the relevance of studying public perception of such perpetrators.

The results from this study show that, in general, women and men share a not so divergent perception of sex offenders. Contrary to our expectations, findings reveal that men and women endorse similar perceptions about sex offenders. This reveals that sex is not a relevant variable when predicting perceptions of sex offenders, suggesting that other gender-related variables, such as sexism, are much more relevant in the explanation of these beliefs. Furthermore, results indicate that the attitudinal and personal variables introduced as correlates (i.e., Ambivalent Sexism, General Punitiveness, and Ability to Recognize Violence) are stronger and more reliable predictors of the perceptions that the community holds toward sex offenders than sociodemographic ones, at least in the present sample.

Finally, since results suggest that negative beliefs about sex offenders are still supported by society, findings from this research indicate that educating the public about sexual offenses, sexual victimization, and sexual offenders needs to be an imperative issue for legislatures and politicians [26]. Precise and empirically based information regarding sex offenders is needed to reshape public perceptions. This is important because educating society leads to a significant change in social policy for these offenders, possibly having a great impact on community support, thus reducing sex offenders' recidivism [74].

Author Contributions: Conceptualization, C.M.L.; methodology, C.R.; software, C.R.; formal analysis, C.R.; writing—original draft preparation, C.M.L. and C.R.; writing-review and editing, C.M.L. and C.R. All authors have read and agreed to the published version of the manuscript.

Funding: This research received no external funding. 
Institutional Review Board Statement: The study was conducted according to the guidelines of the Declaration of Helsinki and was approved by the Ethics Committee of the University of Turin, Italy (CERP 196412-23 March 2021).

Informed Consent Statement: Informed consent was obtained from all subjects involved in the study.

Data Availability Statement: The data presented in this study are available on request from the corresponding author. The data are not publicly available due to ethical consent limitations.

Conflicts of Interest: The authors declare no conflict of interest.

\section{References}

1. World Report on Violence and Health. Available online: http://apps.who.int/iris/bitstream/handle/10665/42495/9241545615 _eng.pdf;jsessionid=6F3F7DB2E8747AB0C9D0CAFE6143E14A? sequence=1 (accessed on 27 October 2021).

2. Council of Europe Convention on Preventing and Combating Violence against Women and Domestic Violence. Available online: https:/ /rm.coe.int/168008482e (accessed on 27 October 2021).

3. National Intimate Partner and Sexual Violence Survey: 2015 Data Brief-Updated Release. Available online: https: / /www.cdc. gov/violenceprevention/pdf/2015data-brief508.pdf (accessed on 27 October 2021).

4. Violence against Women: An EU-Wide Survey. Main Results Report. Available online: https://fra.europa.eu/sites/default/files/ fra-2014-vaw-survey-at-a-glance-oct14_es.pdf (accessed on 27 October 2021).

5. The Impact of Sexual Violence. Available online: https://www.nsvrc.org/sites/default/files/2016-01/saam_2016_impact-ofsexual-violence.pdf (accessed on 1 December 2021).

6. Ferraro, K.F. Fear of Crime: Interpreting Victimization Risk; State University of New York Press: Albany, NY, USA, 1995.

7. León, C.M.; Butler, L.F.; Aizpurua, E. Correlates of fear of victimization among college students in Spain: Gender differences and similarities. J. Interpers. Violence 2020, 088626052091456. [CrossRef]

8. Pryce, D.K.; Wilson, G.; Fuller, K. Gender, age, crime victimization, and fear of crime: Findings from a sample of Kenyan college students. Security 2018, 31, 821-840. [CrossRef]

9. Warr, M. Fear of victimization: Why are women and the elderly more afraid? Soc. Sci. Q. 1984, 65, 681-702.

10. Cook, C.L.; Fox, K.A. Testing the relative importance of contemporaneous offenses: The impacts of fear of sexual assault versus fear of physical harm among men and women. J. Crim. Justice 2012, 40, 142-151. [CrossRef]

11. Lane, J.; Fox, K. Fear of property, violent, and gang crime. Crim. Justice Behav. 2013, 40, 472-496. [CrossRef]

12. Olver, M.E.; Barlow, B.A. Public attitudes toward sex offenders and their relationship to personality traits and demographic characteristics. Behav. Sci. Law 2010, 28, 832-849. [CrossRef]

13. Brown, S.; Deakin, J.; Spencer, J. What people think about the management of sex offenders in the community. Howard J. Crim. Justice 2008, 47, 259-274. [CrossRef]

14. McGhee, M. Two Strikes and You're Dead: Public Opinion on Capital Punishment for Sex Offenders. Ph.D. Thesis, University of Oklahoma, Norman, OK, USA, 2008.

15. Mercado, C.C.; Alvarez, S.; Levenson, J. The impact of specialized sex offender legislation on community reentry. Sex. Abus. 2008, 20, 188-205. [CrossRef]

16. DeLuca, J.S.; Vaccaro, J.; Rudnik, A.; Graham, N.; Giannicchi, A.; Yanos, P.T. Sociodemographic predictors of sex offender stigma: How politics impact attitudes, social distance, and perceptions of sex offender recidivism. Int. J. Offender Ther. Comp. Criminol. 2017, 62, 2879-2896. [CrossRef]

17. Klein, J.L.; Cooper, D.T. Punitive attitudes toward sex offenders: Do moral panics cause community members to be more punitive? Crim. Justice Policy Rev. 2019, 30, 948-968. [CrossRef]

18. Shields, R.T.; Cochran, J.C. The gender gap in sex offender punishment. J. Quant. Criminol. 2020, 36, 95-118. [CrossRef]

19. Höing, M.A.; Petrina, R.; Duke, L.H.; Völlm, B.; Vogelvang, B. Community support for sex offender rehabilitation in Europe. Eur. J. Criminol. 2016, 13, 491-516. [CrossRef]

20. Eagly, A.H.; Chaiken, S. The Psychology of Attitudes; Harcourt Brace Jovanovich College Publishers: Orlando, FL, USA, 1993.

21. Breckler, S.J. Empirical validation of affect, behavior, and cognition as distinct components of attitude. J. Pers. Soc. Psychol. 1984, 47, 1191-1205. [CrossRef]

22. Hogue, T.E. Attitudes to Sex Offenders; University of Lincoln: Lincoln, UK, 2015.

23. Harper, C.A.; Hogue, T.E. Measuring public perceptions of sex offenders: Reimagining the Community Attitudes Toward Sex Offenders (CATSO) scale. Psychol. Crime Law 2015, 21, 452-470. [CrossRef]

24. Jussim, L. Social Perception and Social Reality: Why Accuracy Dominates Bias and Self-Fulfilling Prophecy; Oxford University Press: New York, NY, USA, 2012. [CrossRef]

25. Harper, C.A.; Hogue, T.E.; Bartels, R.M. Attitudes towards sexual offenders: What do we know, and why are they important? Aggress. Violent Behav. 2017, 34, 201-213. [CrossRef]

26. Duncan, J. Public Perceptions Regarding Sex Offenders and Sex Offender Management. Unpublished Master's Thesis, East Tennessee State University, Tennessee, TN, USA, 2012. 
27. Aizpurúa, E. Las Actitudes Punitivas de los Españoles: Alcance, Medición y Factores Explicativos. Doctoral Dissertation, University of Castilla-La Mancha, Castilla-La Mancha, Spain, 2015.

28. Pickett, J.T.; Mancini, C.; Mears, D.P.; Gertz, M. Public (mis)understanding of crime policy: The effects of criminal justice experience and media reliance. Crim. Justice Policy Rev. 2015, 26, 500-522. [CrossRef]

29. Manchak, S.M.; Fisher, L.R. An examination of multiple factors influencing support for sex offender policy. Crim. Justice Policy Rev. 2017, 30, 925-947. [CrossRef]

30. Heller, W. Poverty: The most challenging condition of prisoners release. Georget. J. Poverty Law Policy 2006, XIII, $219-248$.

31. Levenson, J.S.; Cotter, L.P. The impact of sex offender residence restrictions: 1,000 feet from danger or one step from absurd? Int. J. Offender Ther. Comp. Criminol. 2005, 49, 168-178. [CrossRef] [PubMed]

32. Tewksbury, R. Collateral consequences of sex offender registration. J. Contemp. Crim. Justice 2005, 21, 67-81. [CrossRef]

33. Calkins, C.; Colombino, N.; Matsuura, T.; Jeglic, E. Where do sex crimes occur? How an examination of sex offense location can inform policy and prevention. Int. J. Comp. Appl. Crim. Justice 2015, 39, 99-112. [CrossRef]

34. Pickett, J.T.; Mancini, C.; Mears, D.P. Vulnerable victims, monstrous offenders, and unmanageable risk: Explaining public opinion on the social control of sex crime. Criminology 2013, 51, 729-759. [CrossRef]

35. Cohen, M.; Jeglic, E.L. Sex Offender Legislation in the United States: What do we know? Int. J. Offender Ther. Comp. Criminol. 2007, 51, 369-383. [CrossRef]

36. Mancini, C.; Mears, D.P. Sex Offenders-America's new witches? A theoretical analysis of the emergence of sex crime laws. Deviant Behav. 2016, 37, 419-438. [CrossRef]

37. Hanson, K.R.; Morton-Bourgon, K.E. The characteristics of persistent sexual offenders: A meta-analysis of recidivism studies. J. Consult. Clin. Psychol. 2005, 73, 1154-1163. [CrossRef] [PubMed]

38. Willis, G.M.; Malinen, S.; Johnston, L. Demographic differences in public attitudes towards sex offenders. Psychiatr. Psychol. Law 2013, 20, 230-247. [CrossRef]

39. Hsieh, M.; Hamilton, Z.; Zgoba, K.M. Prison experience and reoffending: Exploring the relationship between prison terms, institutional treatment, infractions, and recidivism for sex offenders. Sex. Abus. 2018, 30, 556-575. [CrossRef]

40. Maruna, S.; King, A. Once a criminal, always a criminal? 'Redeemability' and the psychology of punitive public attitudes. Eur. J. Crim. Pol. Res. 2009, 15, 7-24. [CrossRef]

41. Rogers, D.L.; Ferguson, C.J. Punishment and rehabilitation attitudes toward sex offenders versus nonsexual offenders. J. Aggress. Maltreat. Trauma 2011, 20, 395-414. [CrossRef]

42. Budd, K.; Desmond, S.A. Sex offenders and sex crime recidivism: Investigating the role of sentence length and time served. Int. J. Offender Ther. 2014, 58, 1481-1499. [CrossRef]

43. Marteache, N. Deliberative processes and attitudes toward sex offenders in Spain. Eur. J. Criminol. 2012, 9, 159-175. [CrossRef]

44. Malinen, S.; Willis, G.W.; Johnston, L. Might informative media reporting of sexual offending influence community members' attitudes towards sex offenders? Psychol. Crime Law 2014, 20, 535-552. [CrossRef]

45. McCartan, K.F. Student/trainee-professional implicit theories of paedophilia. Psychol. Crime Law 2010, 16, 265-288. [CrossRef]

46. Mancini, C.; Budd, K.M. Is the public convinced that "nothing works?" Predictors of treatment support for sex offenders among Americans. Crime Delinq. 2016, 62, 777-799. [CrossRef]

47. Shackley, M.; Weiner, C.; Day, A.; Willis, G.W. Assessment of public attitudes towards sex offenders in an Australian population. Psychol. Crime Law 2014, 20, 553-572. [CrossRef]

48. Higgins, C.; Ireland, C.A. Attitudes towards male and female sex offenders: A comparison of forensic staff, prison officers and the general public in Northern Ireland. Br. J. Forensic Pract. 2009, 11, 14-19. [CrossRef]

49. Kjelsberg, E.; Loos, L.H. Conciliation or condemnation? Prison employees' and young peoples' attitudes towards sexual offenders. Int. J. Forensic Ment. 2008, 7, 95-103. [CrossRef]

50. Radley, L. Attitudes toward sex offenders. Forensic Update 2011, 66, 5-9.

51. Katz-Schiavone, S.; Levenson, J.S.; Ackerman, A. Myths and facts about sexual violence: Public perceptions and implications for prevention. J. Crim. Justice Pop. Cult. 2008, 15, 291-311.

52. Sahlstrom, K.J.; Jeglic, E.L. Factors affecting attitudes toward juvenile sex offenders. J. Child Sex. Abus. 2008, 17, 180-196. [CrossRef]

53. Bosworth, M. Deportation, detention and foreign-national prisoners in England and Wales. Citizsh. Stud. 2011, 15, 583-595. [CrossRef]

54. Frost, N.A. Beyond public opinion polls: Punitive public sentiment \& criminal justice policy. Sociol. Compass 2010, 4, 156-168. [CrossRef]

55. Glick, P.; Fiske, S.T. The ambivalent sexism inventory: Differentiating hostile and benevolent sexism. J. Personal. Soc. Psychol. 1996, 70, 491-512. [CrossRef]

56. Rollero, C.; De Piccoli, N. Myths about Intimate Partner Violence and moral disengagement: An analysis of sociocultural dimensions sustaining violence against women. Int. J. Environ. Res. Public Health 2020, 17, 8139. [CrossRef]

57. Yamawaki, N. Differences between Japanese and American college students in giving advice about help seeking to rape victims. J. Soc. Psychol. 2007, 147, 511-530. [CrossRef] [PubMed]

58. Viki, G.T.; Abrams, D.; Masser, B. Evaluating stranger and acquaintance rape: The role of benevolent sexism in perpetrator blame and recommended sentence length. Law Hum. Behav. 2004, 28, 295-303. [CrossRef] [PubMed] 
59. Rollero, C.; Bergagna, E.; Tartaglia, S. What is violence? The role of sexism and social dominance orientation in recognizing violence against women. J. Interpers. Violence 2019, 0886260519888525. [CrossRef]

60. Ortabag, T.; Ozdemir, S.; Bebis, H.; Ceylan, S. Perspectives of young adult men regarding violence against women: A crosssectional study from Turkey. J. Fam. Violence 2014, 29, 665-674. [CrossRef]

61. LeBel, T.P.; Burnett, R.; Maruna, S.; Bushway, S. The 'chicken and egg' of subjective social factors and desistance from crime. Eur. J. Criminol. 2008, 5, 131-153. [CrossRef]

62. Shaver, K.G. Defensive attribution: Effects of severity and relevance on the responsibility assigned for an accident. J. Personal. Soc. Psychol. 1970, 14, 101-113. [CrossRef]

63. Suarez, E.; Gadalla, T.M. Stop blaming the victim: A meta-analysis on rape myths. J. Interpers. Violence 2010, 25, 2010-2035. [CrossRef] [PubMed]

64. Rollero, C.; Glick, P.; Tartaglia, S. Psychometric properties of short versions of the Ambivalent Sexism Inventory and Ambivalence Toward Men Inventory. TPM Test. Psychom. Methodol. Appl. Psychol. 2014, 21, 149-159. [CrossRef]

65. Glick, P.; Fiske, S.T. The ambivalence toward men inventory. Psychol. Women Quart. 1999, 23, 519-536. [CrossRef]

66. Gluck, M.; Heesacker, M.; Choi, H.D. How much of the dark triad is accounted for by sexism? Personal. Individ. Differ. 2020, 154, 109728. [CrossRef]

67. León, C.M.; Aizpurúa, E. Do sexist attitudes persist in college students? An analysis of its prevalence, predictors, and gender differences. Educación XX1 2020, 23, 275-296. [CrossRef]

68. Colémont, A.; Van Hiel, A.; Cornelis, I. Five-Factor Model personality dimensions and right-wing attitudes: Psychological bases of punitive attitudes? Personal. Individ. Differ. 2011, 50, 486-491. [CrossRef]

69. Emmers-Sommer, T.M. College student perceptions of hypothetical rape disclosures: Do relational and demographic variables pose a risk on disclosure believability? Sex. Cult. 2017, 21, 664-679. [CrossRef]

70. Powers, R.A.; Leili, J.; Hangman, B.; Cohn, A. The impact of college education on rape myth acceptance, alcohol expectancies, and bystander attitudes. Deviant Behav. 2015, 36, 489-500. [CrossRef]

71. Vonderhaar, R.L.; Carmody, D.C. There are no "innocent victims" the influence of just world beliefs and prior victimization on rape myth acceptance. J. Interpers. Violence 2015, 30, 1615-1632. [CrossRef]

72. Allport, G.W.; Clark, K.; Pettigrew, T. The Nature of Prejudice; Doubleday: New York, NY, USA, 1954.

73. Cochran, J.C.; Toman, E.L.; Shields, R.T.; Mears, D.P. A uniquely punitive turn? Sex offenders and the persistence of punitive sanctioning. J. Res. Crime Delinq. 2021, 58, 74-118. [CrossRef]

74. Cochran, J.K.; Chamlin, M.B. Can information change public opinion? Another test of the Marshall hypotheses. J. Crim. Justice 2005, 33, 573-584. [CrossRef] 